\title{
Development of Processes and Equipment for the Refabrication of HTGR Fuels
}

\author{
John D. Sease \\ A. L. Lotts
}

\section{OAK RIDGE NATIONAL LABORATORY}




\section{DISCLAIMER}

This report was prepared as an account of work sponsored by an agency of the United States Government. Neither the United States Government nor any agency Thereof, nor any of their employees, makes any warranty, express or implied, or assumes any legal liability or responsibility for the accuracy, completeness, or usefulness of any information, apparatus, product, or process disclosed, or represents that its use would not infringe privately owned rights. Reference herein to any specific commercial product, process, or service by trade name, trademark, manufacturer, or otherwise does not necessarily constitute or imply its endorsement, recommendation, or favoring by the United States Government or any agency thereof. The views and opinions of authors expressed herein do not necessarily state or reflect those of the United States Government or any agency thereof. 


\section{DISCLAIMER}

Portions of this document may be illegible in electronic image products. Images are produced from the best available original document. 


\section{Printed in the United States of America. Available from National Technical Information Service \\ U.S. Department of Commerce \\ 5285 Port Royal Road, Springfield, Virginia 22161 \\ Price: Printed Copy $\$ 4.00$; Microfiche $\$ 2.25$}

This report was prepared as an account of work sponsored by the United States Government. Neither the United States nor the Energy Research and Development Administration/United States Nuclear Regulatory Commission, nor any of their employees, nor any of their contractors, subcontractors, or their employees, makes any warranty, express or implied, or assumes any legal liability or responsibility for the accuracy, completeness or usefulness of any information, apparatus, product or process disclosed, or represents that its use would not infringe privately owned rights. 
ORNL/TM-5334

UC-77 (Gas-Cooled

Reactor Technology)

\author{
Contract No. W-7405-eng-26 \\ METALS AND CERAMICS DIVISION \\ THORIUM UTILIZATION PROGRAM
} DEVELOPMENT OF PROCESSES AND EQUIPMENT FOR THE
REFABRICATION OF HTGR FUELS

John D. Sease and A. L. Lotts

JUNE 1976

This report was prepared as an account of work Writes Government. Neither the Uniled States nor the United States Energy theirch an subcontractors, or their employees. makes any warranty, express or implied, ot assumes any lege liability or responsoliny for the accuracy, comple or usefulness of any information, appats use would not process disclosed, or represents th

infringe privately owned rights.

NOTICE This document contains information of a preliminary nature and was prepared primarily for internal use at the Oak Ridge National Laboratory. It is subject to revision or correction and therefore does not represent a final report.

OAK RIDGE NATIONAL LABORATORY

Oak Ridge, Tennessee 37830

operated by

UNION CARBIDE CORPORATION

for the

ENERGY RESEARCH AND DEVELOPMENT ADMINISTRATION 


\section{THIS PAGE WAS INTENTIONALLY LEFT BLANK}


CONTENTS

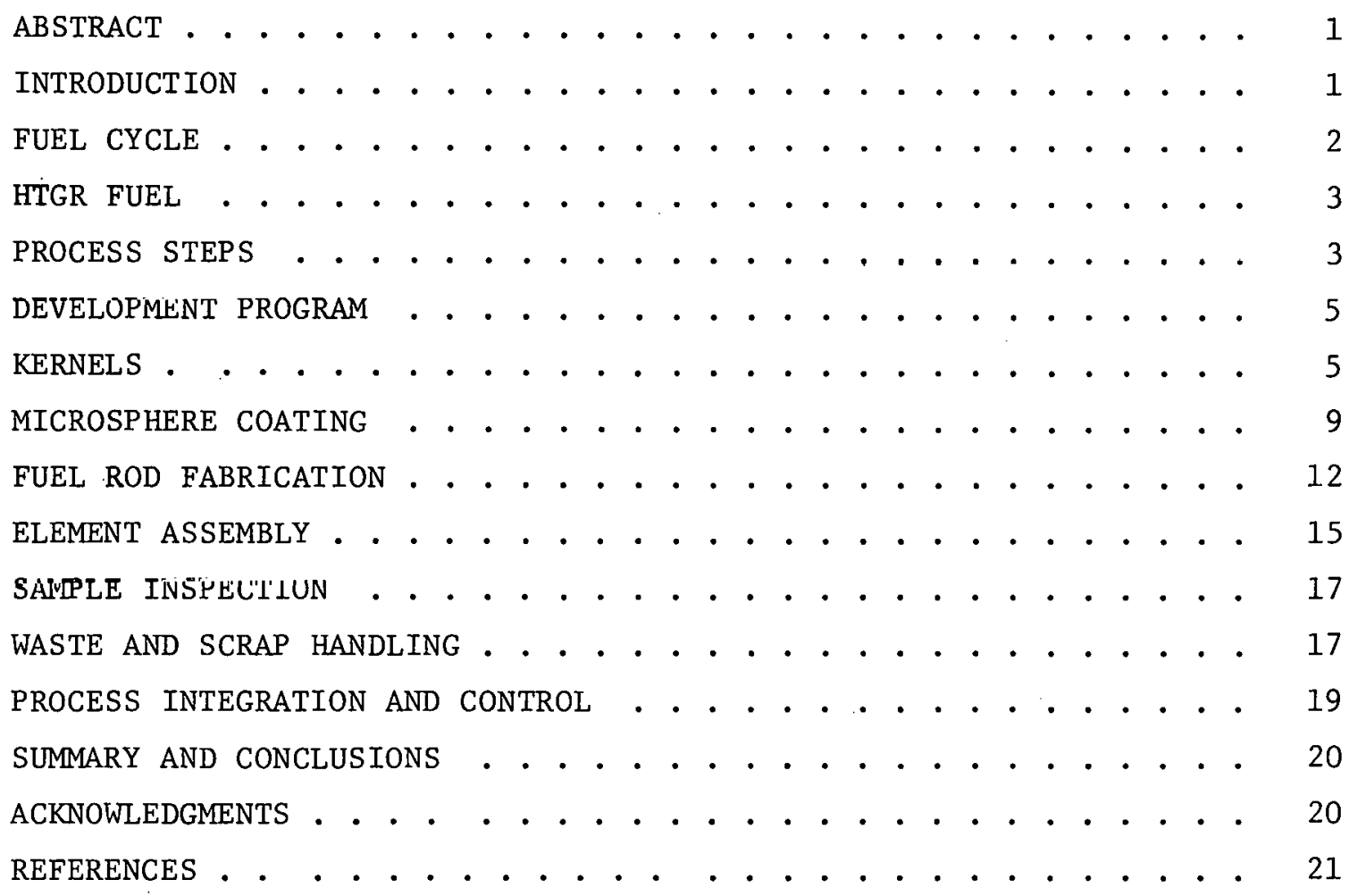


DEVELOPMENT OF PROCESSES AND EQUIPMENT FOR THE REFABRICATION OF HTGR FUELS

John D. Sease and A. L. Lotts

\title{
ABSTRACT
}

\begin{abstract}
Refabrication is in the step in the HTGR thorium fuel cycle that begins with a nitrate solution containing ${ }^{23}{ }^{3} \mathrm{U}$ and culminates in the assembly of this material into fuel elements for use in an HTGR. Refabrication of HTGR fuel is essentially a manufacturing operation and consists of preparation of fuel kernels, application of multiple layers of pyrolytic carbon and SiC, preparation of fuel rods, and assembly of fuel rods in fuel elements. All the equipment for refabrication of ${ }^{2}{ }^{3} \mathrm{U}$-contalning fuel must be designed for completely remote operation and maintenance in hot cell facilities. This paper describes the status of processes and equipment development for the remote refabrication of HTGR fuels. The feasibility of H'IGR refabrication processes has been proven by laboratory development. Engineering-scale development is now being performed on a unit basis on the majority of the major equipment items. Engineering-scale equipment described includes full-scale resin loading equipment, a 5-in. -diam $(0.13-\mathrm{m})$ microsphere coating furnace, a fuel rod forming machine, and a cure-inplace furnace.
\end{abstract}

\section{INTRODIISTTON}

Refabrication is the step in the High-Temperature Gas-Cooled Reactor (HTGR) fuel cycle that begins with the receipt of the nitrate solution containing ${ }^{23} \mathrm{U}$ and culminates in the assembly of this material into fuel elements for use in an HTGR. Within the last year or so, several design studies have more clearly focused on the overall requirements for the refabrication of HTGR fuels. These studies included the conceptual design of a refabrication pilot plant at ORNL (1) and a design study of a conmerctal recycle facility by General Atomic Company (2). These design studies indicated that a commercial recycle plant for both reprocessing and refabrication will cost in the range of one-half to three fourth of a billion dollars. Refabrication is the single most expensive portion of this plant and accounts for about $40 \%$ of the total plant cost. This is compared with about $25 \%$ for reprocessing, $20 \%$ for element handling, and $15 \%$ for waste processing. To date, approximately 
twenty million dollars has been spent on HTGR refabrication development in this country. The current level of effort in the U.S. is about six million dollars per year. It has been estimated that the refabrication development necessary for a commercial recycle facility will cost two to three hundred million dollars, including the cost for a demonstration facility. The expense involved in developing HTGR recycle capabilities has lead the U.S. and the Federal Republic of Germany into negotiations to establish a cooperative program.

\section{FUEL CYCLE}

The fuel cycle for the thorium-cycle HTGR is shown in tig. 1. In the fuel cycle, about $40 \%$ of the requirements for the reactor will be supplied trom bred $233 \mathrm{U}(3)$. Tle ${ }^{3} 3_{U} \mathrm{U}$ produced in an HTGR will be r,nnsiderably less hazardous than plutonium in terms of inhalation; however, for ingestion, HTGR ${ }^{23}{ }^{3} \mathrm{U}$ will be comparable with the plutonium produced in an LMFBR fuel cycle (4). In terms of in-plant personnel radiation exposure, ${ }^{23} \mathrm{U}$ is more difficult to handle than plutonium because of the buildup with time of very high-energy gamma radiation (5). Because of the presence of this radiation ${ }^{233} \mathrm{U}$ must be handled remotely in heavily shielded hot cell facilities. Shield thicknesses in the range of 3 to $4 \mathrm{ft}$ $(0.9-1.2 \mathrm{~m})$ of concrete will be required for refabrication operations.

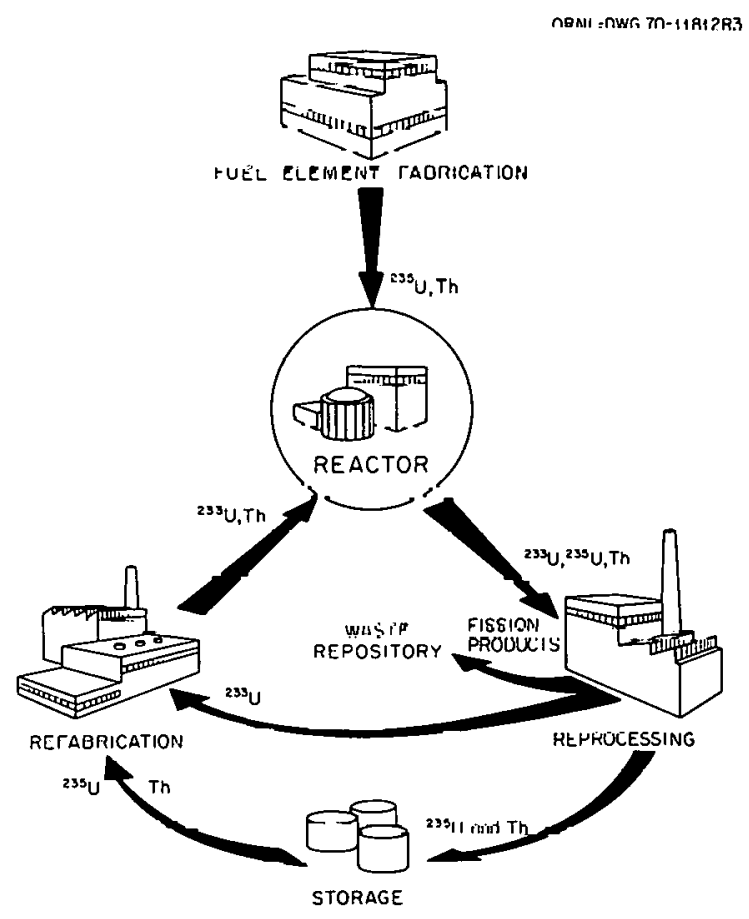

Fig. 1. HTGR Fuel Recycle. 
In a commercial refabrication plant, it is envisioned that the process equipment, because of its relatively large size and complexity, will be located in large canyon-type hot cells. All routine materials handling operations will be accomplished by specially designed pneumatic or electromechanical systems. Equipment will be installed and maintained by remotely operated bridge cranes or electromechanical manipulators. Master-slave manipulators, because of their limited reach and capacity, will be utilized only for limited light-duty operations. Viewing will be direct through shield windows or by remote TV. Direct in-place maintenance of the process equipment will not be possible because of the buildup radioactive particulates in the hot cells. Because of the difficulty and slowness of remote manipulation, on-line maintenance will be accomplished primarily by the substitution of major equipment components. Components will be maintained off-line, either remotely in special facilities or directly after appropriate decontamination in gloved boxes.

A manufacturing operation, such as required in the refabrication of HTGR fuel, has never been done on a commercial scale in this type of heavily shielded remote facility. The majority of the refabrication development work is therefore centered around the development of processes and equipment suitable for remote operation and maintenance. Remote operations are similar to those needed in a highly automated manufacturing operation; however, the maintenance requirements are significantly different and are probably the most dominating factor that characterizes a nuclear refabrication facility. The maintenance requirements are such that essentially all the in-cell process equipment must be capable of completely remote installation and removal.

\section{HTGR FUEL}

The reference fuel configuration for HTGR fuel refabrication development is shown in Fig. 2. The fuel is composed of fertile and fissile microspheres. The fertile particle is coated with two types of pyrolytic carbon (PyC) or a Biso coating. The fissile particle is coated with two types of PyC coating and SiC or a Triso coating. The coated particles are bonded with a carbonaceous matrix into a fuel rod. The fuel rods are then inserted into the holes of a graphite fuel block.

\section{PROCESS STEPS}

The basic manufacturing steps for refabricating HTGR fuel are shown in Fig. 3. These basic steps are essentially the same as those used in fresh fuel manufacture $(6-8)$ and consist of the preparation of fuel kernels, application of multiple layers of PyC and SiC, preparation of fuel compacts or rods, and assembly of fuel rods into a fuel element. Sample inspection and waste and scrap handling are also major process requirements in refabrication of HTGR fuel. Processes and equipment development for fresh fuel manufacture are generally applicable in refabrication. However, the requirements for remote operation and maintenance are so dominating that certain process operations may be different than those required in fresh fuel manufacture. 


\section{HTGR FUEL COMPONENTS}

FISSILE (U-235 OR U-233)

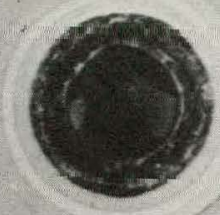

FERTILE (Th-232)

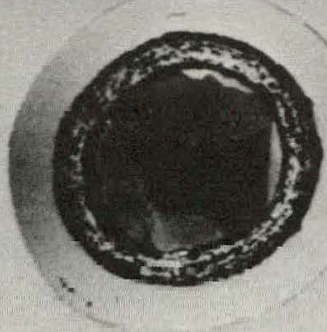

FUEL PARTICLES

SCALE:

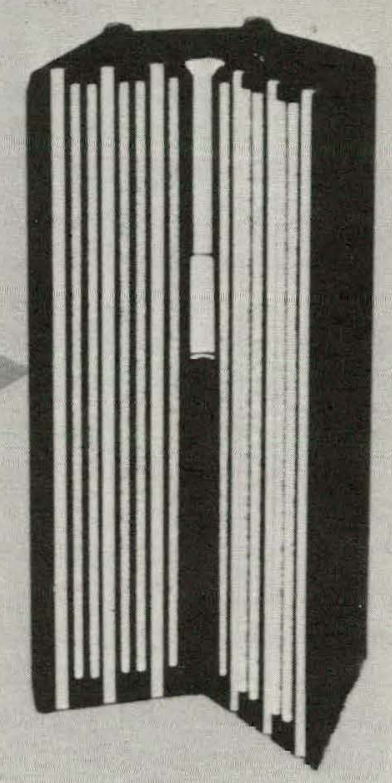

FUEL ROD

$1 x$
FUEL ELEMENT

$1 / 7 \times$

Fig. 2. HTGR Fuel Components.

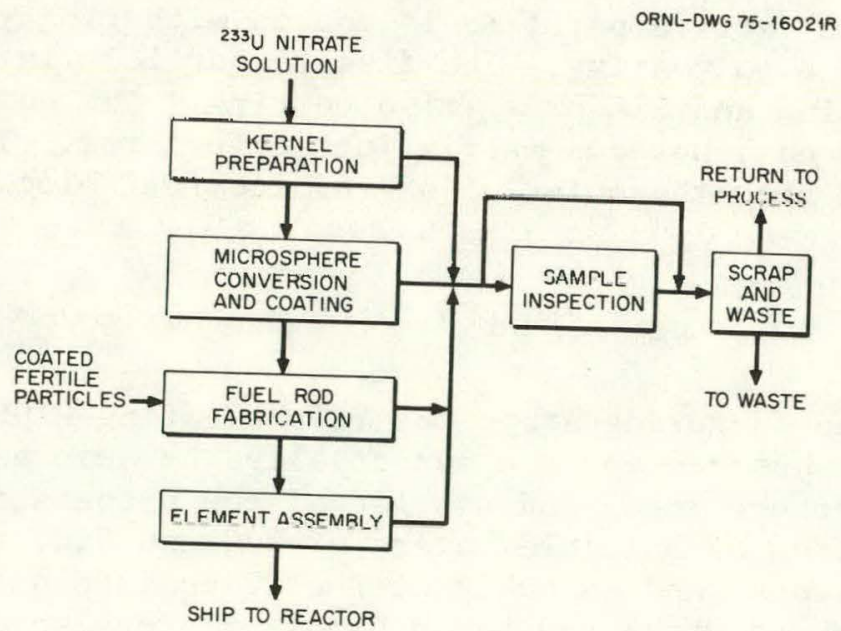

Fig. 3. Process for HTGR Fuel Refabrication. 


\section{DEVELOPMENT PROGRAM}

The overall objective of the development program for HTGR recycle is to provide a technological base so that commercial HTGR refabrication plants can be designed, built, licensed, and operated with an acceptable private investment risk. Current plans are to build a governmentsupported demonstration plant as the last phase of this program. The program leading to this demonstration plant will proceed in phases. The logic of the development program phases for the HTGR Recycle Demonstration Facility (HRDF) is shown in Fig. 4. The terms "cold" and "hot" refer to the absence or presence of significant amounts of radioactivity. The objective of the cold and hot laboratory development is to prove process feasibility. In refabrication development, with the exception of some waste and scrap processes, essentially all this work has been completed. The objective of cold and hot engineering development is to establish the space envelope for the in-cell process equipment. The processes and equipment described in this paper are generally in cold engineering development. Hot engineering tests for kernel manufacture, carbonization, and coating are now being planned. Cold prototype development is necessary to establish the in-cell equipment configuration. This work, which will be done on full-scale equipment, is just beginning. Procedure development will utilize cold prototype equipment and will develop the operating and maintenance procedures necessary for the start-up of the HRDF.

\section{KERNELS}

The first step in refabrication is kernel manufacture. Most "cold" fuel kernels that have been prepared for HTGR applications have been made by powder agglomeration techniques (7). The problems of remote handling of dry powders were dramatically illustrated in the failure of the General Electric Morris, Illinois, reprocessing plant (9), and it is universally agreed that a solution chemistry process is the much preferred route for remote fuel kernel preparation. A number of sol-gel type processes have been developed over the last 15 or so years and appear to be suitable for HTGR applications (10).

Recently, the U.S. adopted a kernel preparation technique of loading uranyl nitrate on ion exchange resin. The principal advantage of the resin route is that the kernel shape can be prepared and upgraded before the introduction of uranium, thus eliminating the forming step from the hot cells. Resin kernels at various stages of manufacture are shown in Fig. 5. The resin is a commercially available ion exchange resin used in the chemical processing industry.

The resin is loaded with uranium and dried at about $110^{\circ} \mathrm{C}$. It is then carbonized to form a $\mathrm{UO}_{2}-\mathrm{C}$ fuel kernel. Subsequent heating converts the kernel to a final carbide or oxycarbide fuel form. The chemical 
ORNL-DWG 76-3315

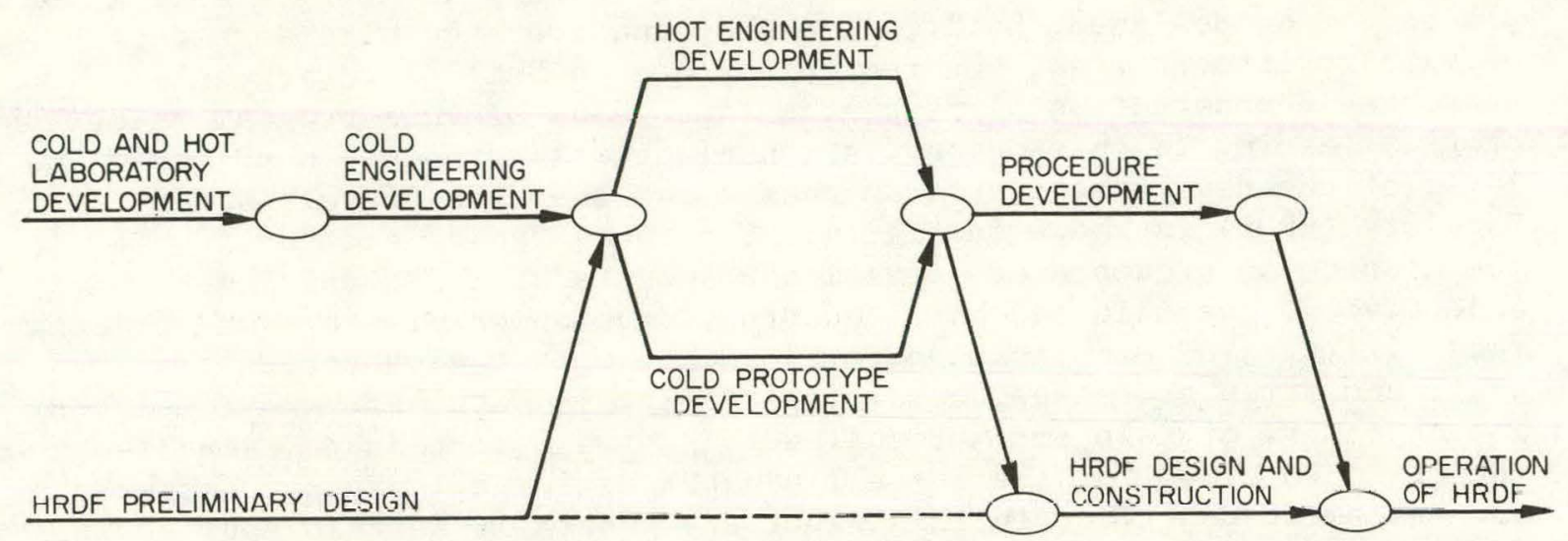

Fig. 4. Logic of Development Program Phases for the Design, Construction, and Operation of an HRDF.

steps involved in loading uranium on ion exchange resin are shown in Fig. 6. In the chemical equilibrium, the loading of the $\mathrm{UO}_{2}{ }^{2+}$ on the hydrogen-form resin releases hydrogen ion. The release of this hydrogen ion tends to drive the reaction to the left, and this limits the uranium loading. The reaction can be driven to the right by preparation of an "acid deficient" uranyl nitrate feed shown as the acid removal step. The acid is removed by an amine in an organic phase. The overall loading reaction is indicated in the last line of the figure. A simplitied resin-loading equipment flowsheet is shown in Fig. 7. The actual resin loading column is shown on the left; the middle portion shows the nitrale extraction arrangement. The process on the right is for regeneration of the solvent.

Engineering-scale resin loading equipment capable of loading about $20 \mathrm{~kg}$ of uranium per day by the flowsheet is now in operation at the Oak Ridge Nationa1 Laboratory. 


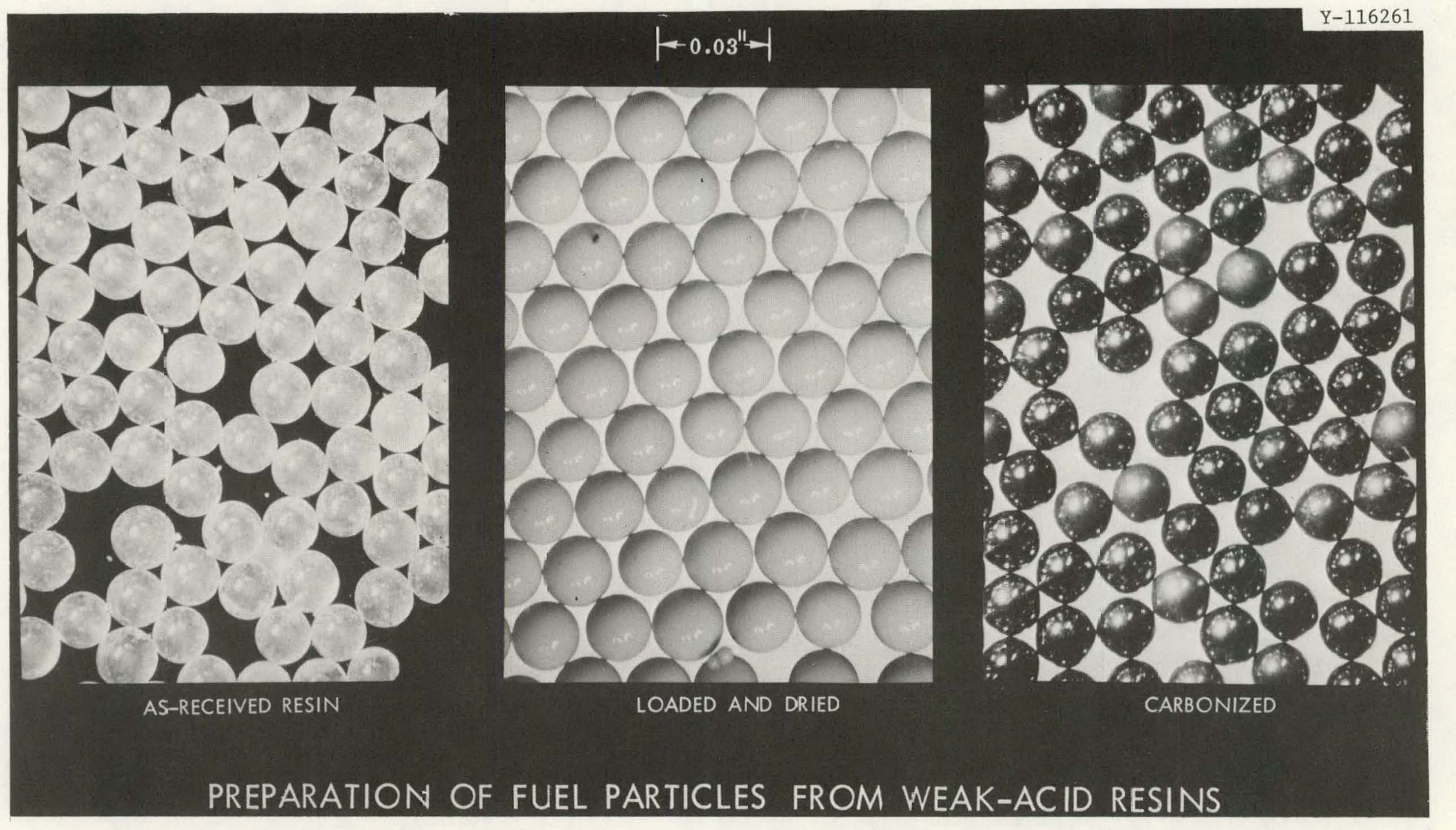

Fig. 5. Resin Kernel in Various Stages of Manufacture. 
ORNL-DWG 75-8987R

Chemical Equilibrium:

$$
2 \operatorname{RESIN}(\mathrm{H})+\mathrm{UO}_{2}^{+2} \rightleftarrows \operatorname{RESIN}_{2}\left(\mathrm{UO}_{2}\right)+2 \mathrm{H}^{+}
$$

Acid Removal:

$$
\begin{aligned}
& \mathrm{UO}_{2}\left(\mathrm{NO}_{3}\right)_{2}+1 / 2 \mathrm{H}_{2} \mathrm{O} \frac{\text { AMINE }}{\text { ORGANIC PHASE }}-\mathrm{UO}_{2}(\mathrm{OH})_{.5}\left(\mathrm{NO}_{3}\right)_{1.5}+1 / 2 \mathrm{HNO}_{3} \\
& \text { HYDROLYSIS "ACID-DEFICIENT" AMINE NITRATE }
\end{aligned}
$$

Loading Reaction:

$$
\mathrm{UO}_{2}(\mathrm{OH}) \cdot 5^{\left(\mathrm{NO}_{3}\right)} 1.5+\operatorname{RESIN}(\mathrm{H}) \longrightarrow \operatorname{RESIN}_{2}\left(\mathrm{HO}_{2}\right)+\mathrm{IIO}_{2}\left(\mathrm{NO}_{3}\right)_{2}
$$

Fig. 6. Simplified Chemical Steps Involved in the Uranium Loading of Weak-Acid Resins Using Amine Extraction of Nitrate.

ORNL DWG 74-6299

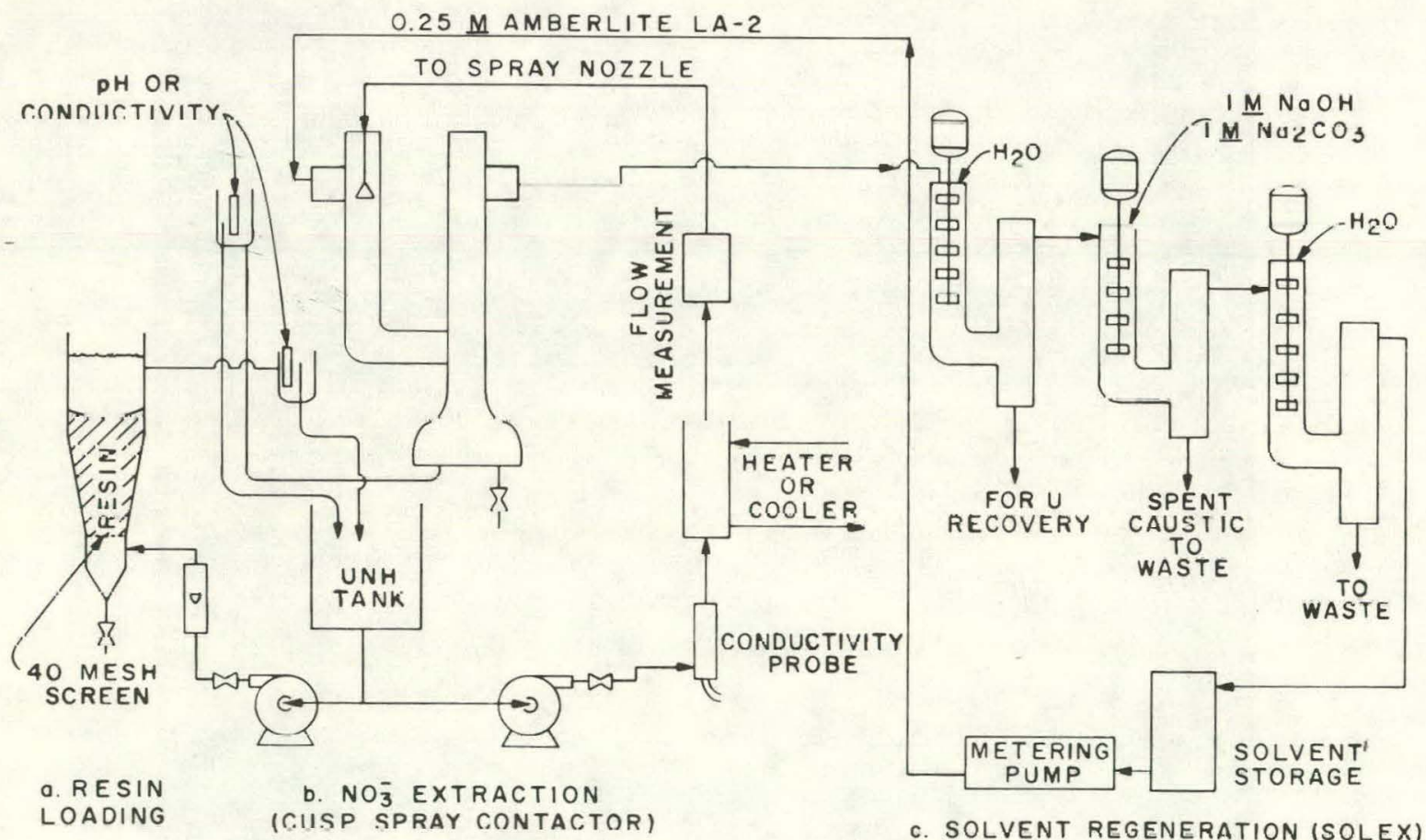

Fig. 7. Resin Loading Equipment Flowsheet. 


\section{MICROSPHERE COATING}

A cross section of a typical coated particle is shown in Fig. 8. This is representative of a Triso-coated fissile particle showing the various $\mathrm{PyC}$ and SiC layers.

The overall microsphere conversion and coating process is shown in

Fig. 9. After kernel formation, the kernels are upgraded to eliminate the oversized, undersized, and misshaped particles. The kernel upgrading step should be minimal, particularly for the resin process. The kernel is then calcined or carbonized, depending upon the kernel formation route. After carbonization or calcination, the conversion of the kernels to an oxycarbide and the various coating operations will be carried out sequentially in a batch fashion in a single coating furnace. This is indicated by the dashed lines around these process steps. After the coating and conversion steps, the coated material will be sizeclassified to remove oversized and undersized material, and then a number of coated batches will be blended to form a large homogenenis lot of matcrial. The coating operation presents some unique problems for remote application as the coating processes are very complex and require precise control of a number of process parameters to make an acceptable product. The coating apparatus, which operates at high temperature, must be serviced after almost every coating run because of the buildup of soot and other deposits in the coating chamber. In addition, the wastes produced during coating include $\mathrm{H}_{2}, \mathrm{HCl}$, and solid wastes greater in quantity than the coating product. A schematic of a 5-in.-diam (0.13-m) engineering-scale coating furnace is shown in Fig. 10. The coating furnace uses a graphite resistance heating element and is designed with a low thermal mass to accommodate the batch coating process with a minimum delay between batches.

Coating is a very expensive step in refabrication, and the unit cost depends largely upon the size of the coating apparatus. Because of criticality considerations, a 5-in. coating chamber has been the accepted size for fissile particle coaters. Recently a fissile particle coater 10 in. $(0.25 \mathrm{~m})$ in diameter has been shown to be acceptable if all moderating material is eliminated, and this coater is currently the reference size for the refabrication development effort. Typically, a single 10-in. coater can coat product containing about $7 \mathrm{~kg}$ U per 24-hr day. In a commercial-scale refabrication plant, ten to twelve 10-in. coaters will be required.

Both the U.S. and the Federal Republic of Germany consider remote coating a key step in HTGR refabrication, and both countries have active programs in this area. In the U.S., considerable progress has been made over the last several years in the implementation of the 5-in. engineering-scale coater for remote applications. Most of the apparatus necessary to remotely operate and maintain this coater has been designed and fabricated. Installation of the equipment is expected to be completed by June 1976. Work has begun on the design of prototypic 10-in. $(0.25-\mathrm{m})$ remote coating equipment. 


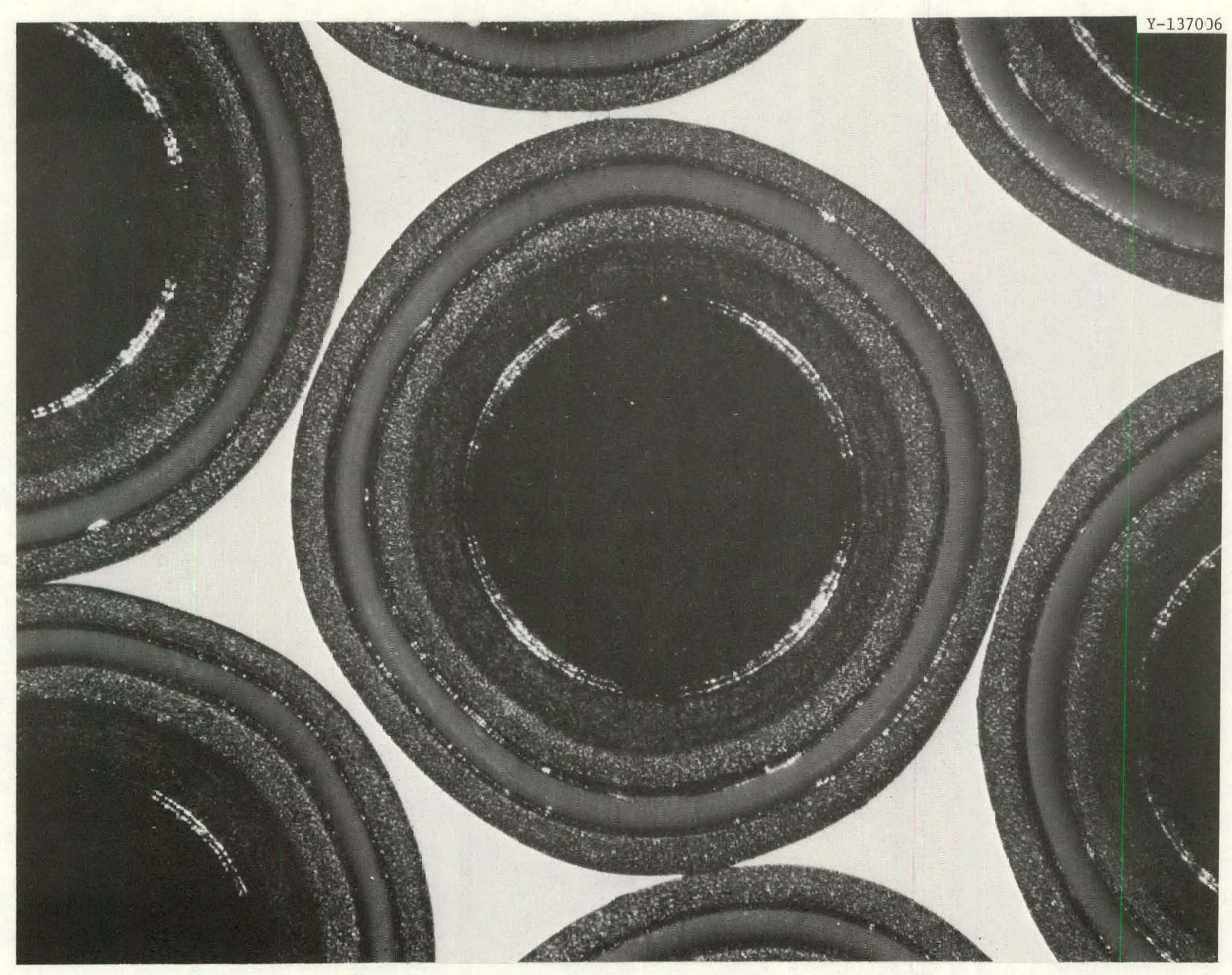

Fig. 8. Typical Triso-Coated Partizles for HTGR Application. 


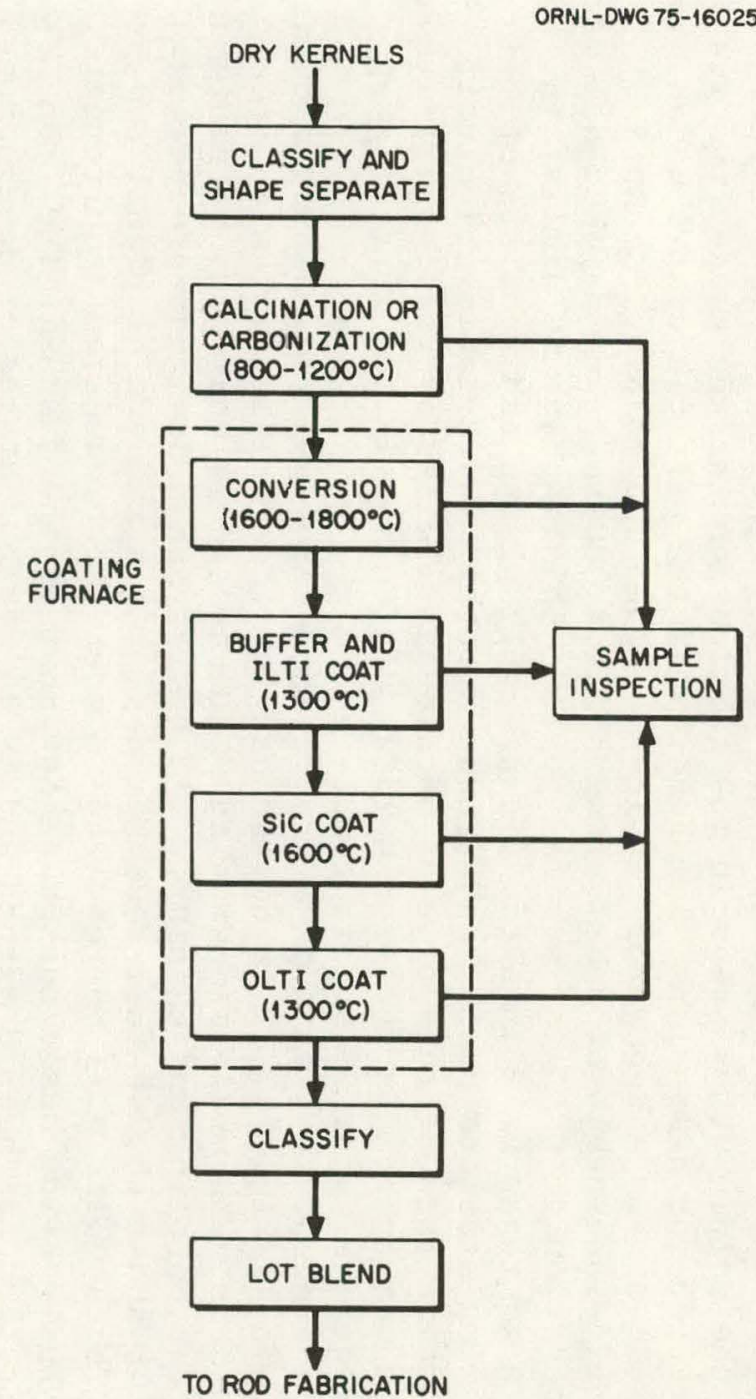

Fig. 9. Microsphere Conversion-Coating

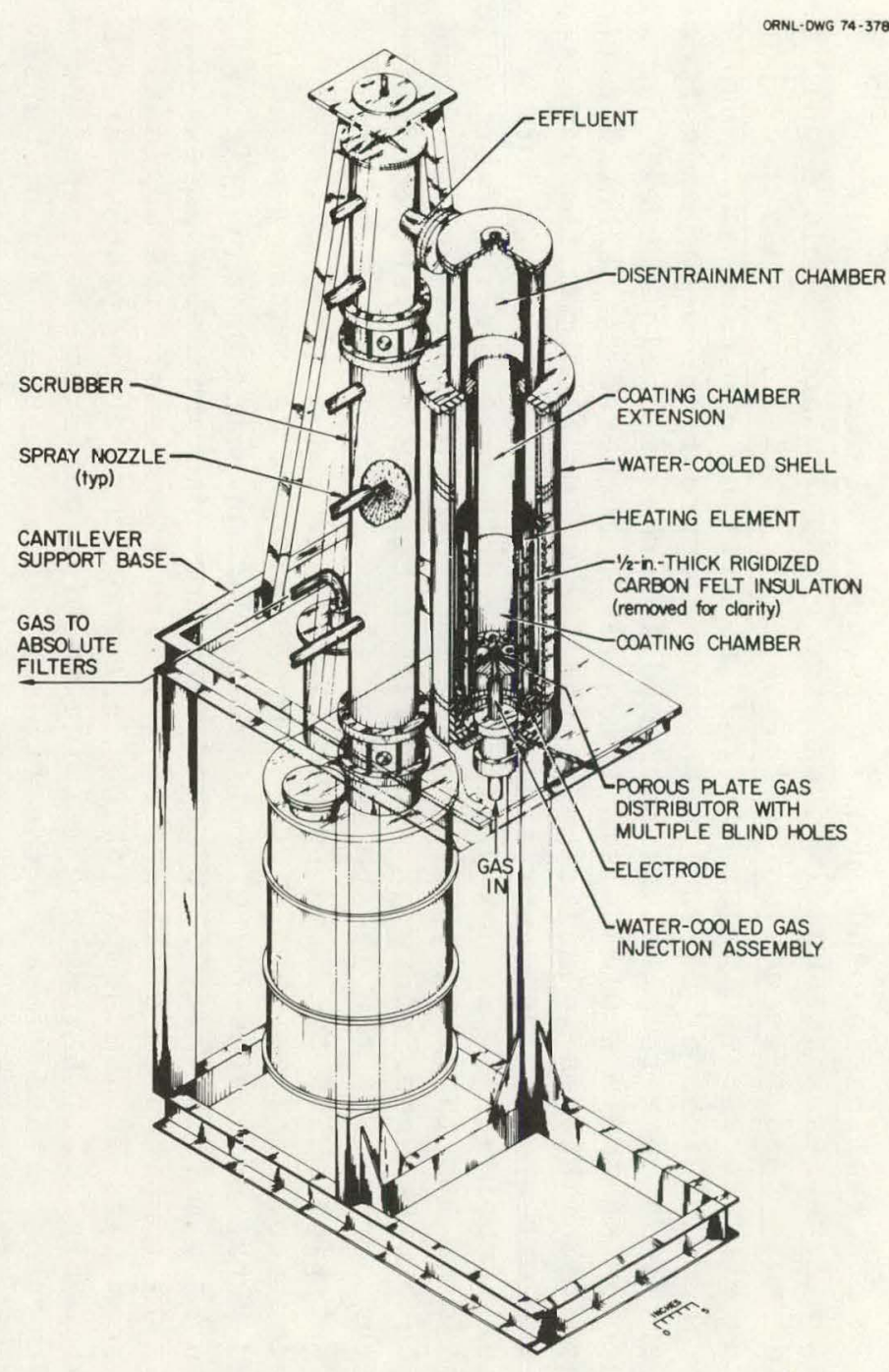
Frocess.

Fig. 10. Engineering-Scale 5-in.-diam (0.13-m) Coating Furnace. 


\section{FUEL ROD FABRICATION}

In rod fabrication and in the subsequent element assembly step, coated microspheres are handled, and the contamination levels should be considerably less. Because of this, several studies have assumed that the in-cell process equipment for rod fabrication and element assembly could be maintained by contact means after appropriate decontamination. However, in a commercial plant designed for contact maintenance, the production schedule could be significantly encumbered by decontamination operations. This is in addition to the design problem for the required life-support systems and isolation needed for personnel entry into a hot cell complex. It is now generally accepted that the rod fabrication and element assembly equipment must be designed for remote maintenance because of the uncertainty of accumulalive effects and upsct conditions that may occur over the 1 - to 20 -year plant 11 relime.

A typical HTrR fuel rod, shown in Fig. 11, is a right circular cylinder about $1 / 2$ in. by 2 in. ( 13 by $50 \mathrm{~mm}$ ) and is composcd of a clusepacked array of coated fertile, fissile, and graphite shim particles bonded by a matrix that is injected into the interstitial spaces. The matrix is composed of a mixture of graphite flour and a thermoplastic petroleum pitch. The steps in the fuel rod fabrication process are shown in Fig. 12. A fuel rod molding machine performs the steps indicated by the dotted block on the figure. They include: (1) dispensing an appropriate quantity of the three particle types for each individual fuel rod, (2) blending the particles, (3) loading them into a cylindrical steel mold, (4) introducing the matrix into the mold on top of the particle bed as a solid slug or pellet, (5) heating the mold to about $180^{\circ} \mathrm{C}$, (6) applying pressure to inject the matrix material into the particle bed, (7) cooling the mold, and (8) ejecting the solid fuel rod from the mold. Other steps in rod fabrication include nondestructive inspection for dimensions, homogeneity of the particle distribution, and uranium assay. A laboratory device for fuel rod molding, shown in Fig. 13, is capable of fabricating about 4,000 rods per day and has been in operation at ORNL for several years. This machine is similar in design to those used in automatic assembly plants and consists of operating stations positioned around a rotary index table. The unit production rate of this type of machine is limited by the longest slep in the sequence. In fuel rod molding, injection is the longest step and requires about $20 \mathrm{sec}$ to complete.

$\Lambda$ conceptual design nf a production-scale fuel rod molding machine is shown in Fig. 14. This device carries the fuel rod molds as free members between various operating stations and is analogous to equipment used for bottling and canning. The device has a designed production rate of about 40,000 fuel rods per day. In a commercial plant, two or three such units will be required to meet the production requirements.

Enginccring-scale equipment for most of the steps in fuel rod fabrication has been designed and is in various stages of development. The design of the production-scale fuel rod forming machine is in the preliminary stage. 


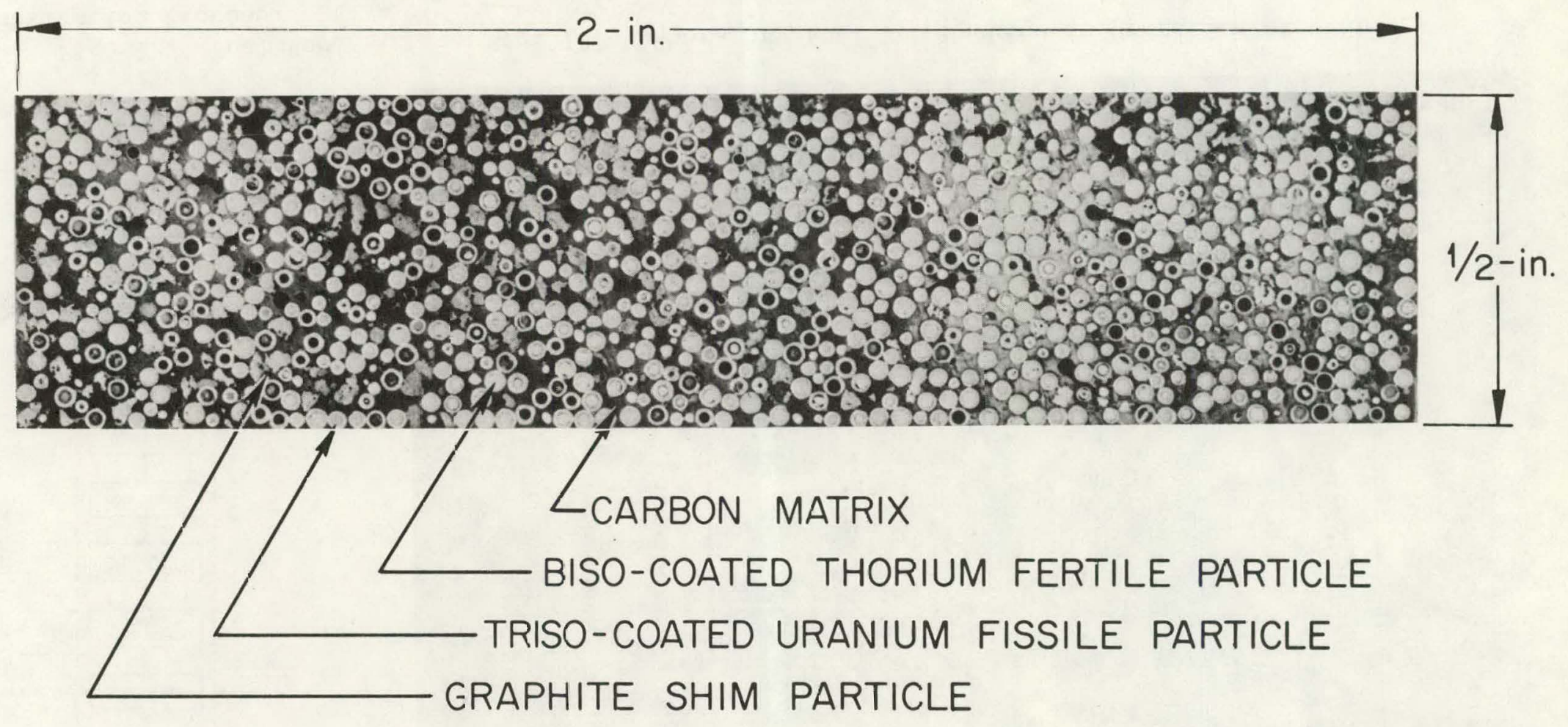

Fig. 11. Cross Section of a Typical HTGR Fuel Rod. 


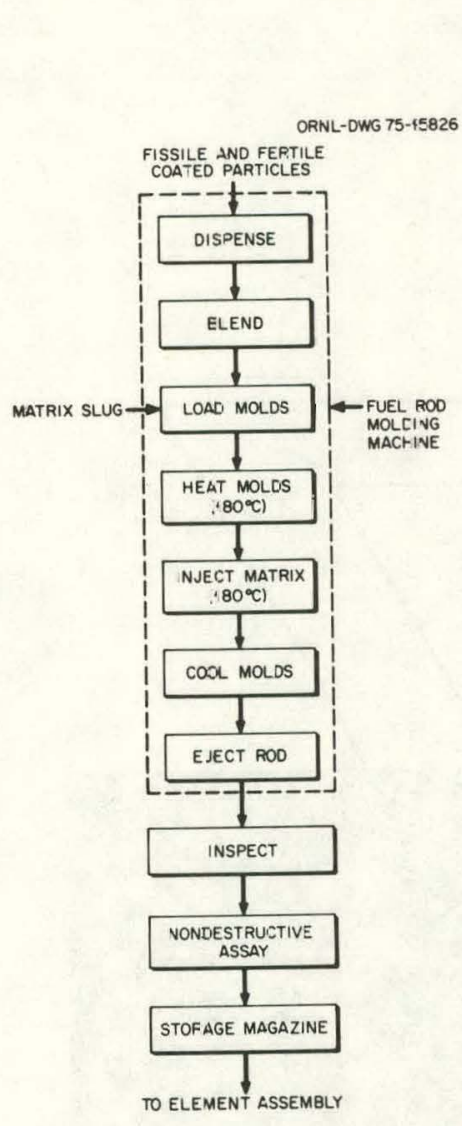

Fig. 12. Fue1 Rod Fabrication Process.

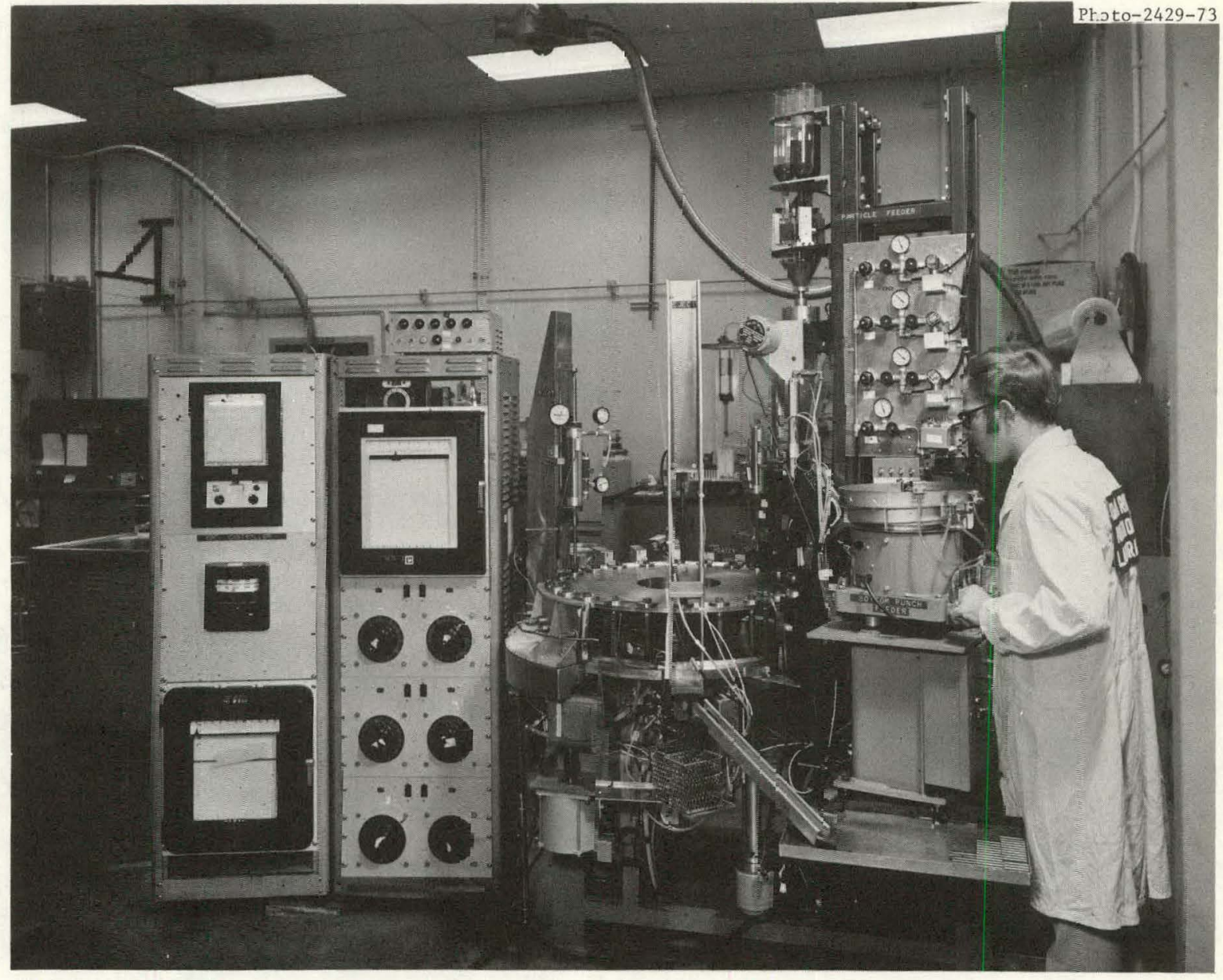




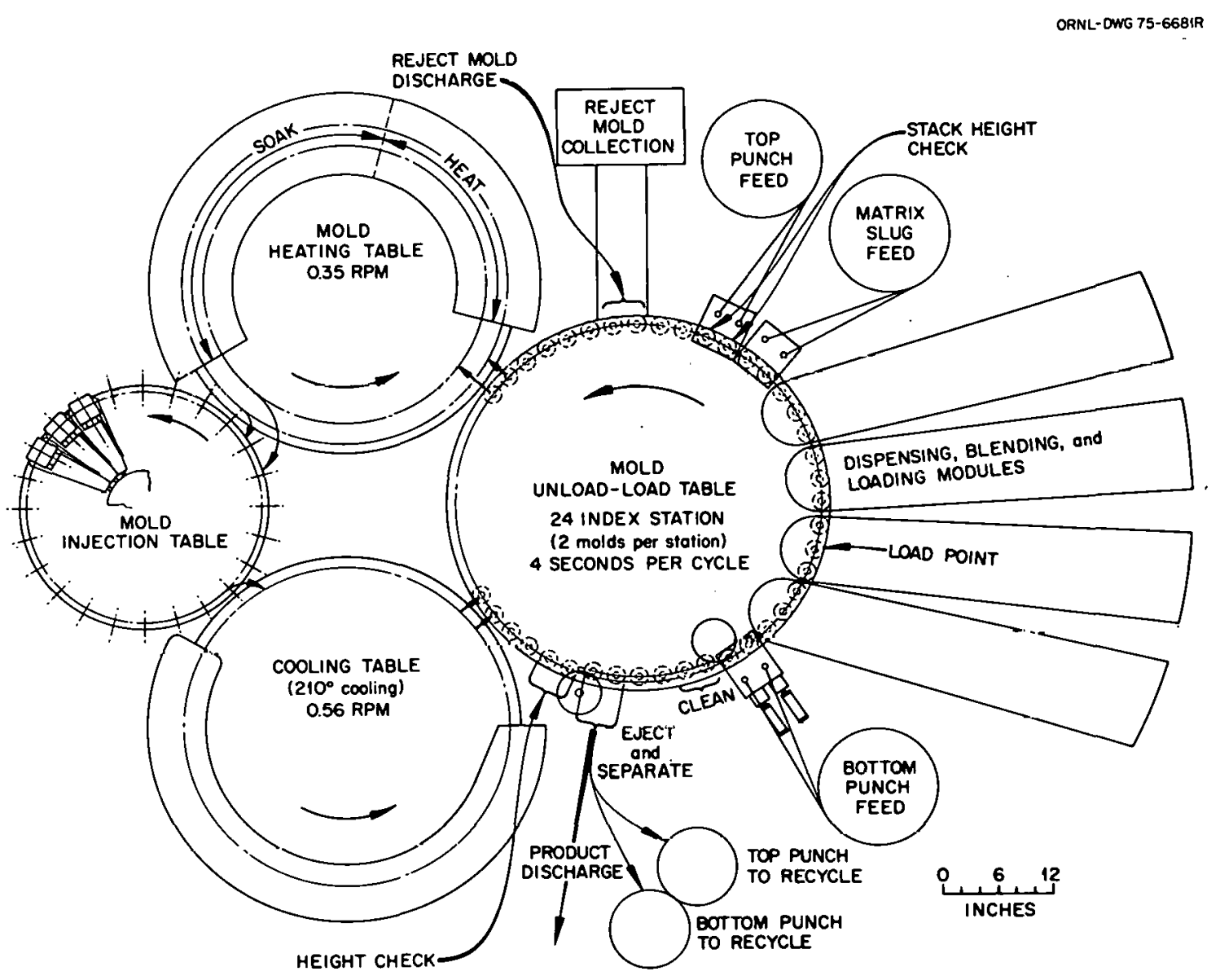

Fig. 14. Conceptual Layout of a Production-Scale Fuel Rod Forming Machine.

\section{ELEMENT ASSEMBLY}

The major process steps in fuel element assembly are shown in Fig. 15. In element assembly, the molded fuel rods are placed into the machined holes in the graphite block, and the entire assembly is heated to $1800^{\circ} \mathrm{C}$ to cure the matrix. The cured element is cleaned and packaged for shipment to the reactor.

In refabrication, the principal problem in element assembly is the design of a furnace to heat the large fuel element to $1800^{\circ} \mathrm{C}$. The cycle time required to heat and cool the fuel element dictates, for economic reasons, that some type of continuous furnace be employed. A vertical furnace configuration was selected for remote application primarily because of its small floor space requirement and the relative ease of vertical assembly and disassembly. A schematic diagram of the furnace designed for processing HTGR fuel elements is shown in Fig. 16. This furnace, which can process 16 fuel elements per day, is about 6 by 6 by $25 \mathrm{ft}$ high $(1.8$ by 1.8 by $7.6 \mathrm{~m}$ ). In a commercial refabrication plant, two to three of these furnaces will be required. The furnace 


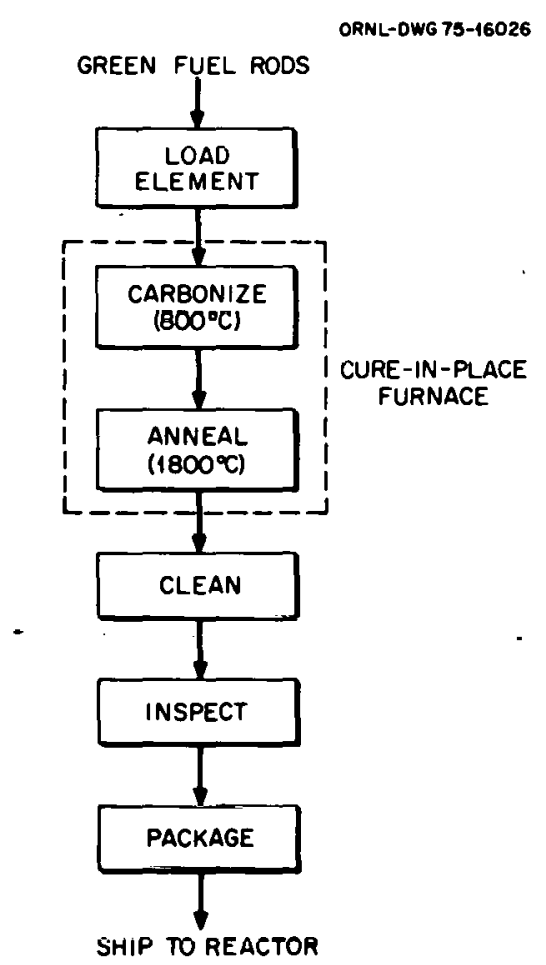

Fig. 15. Element Assembly Process.

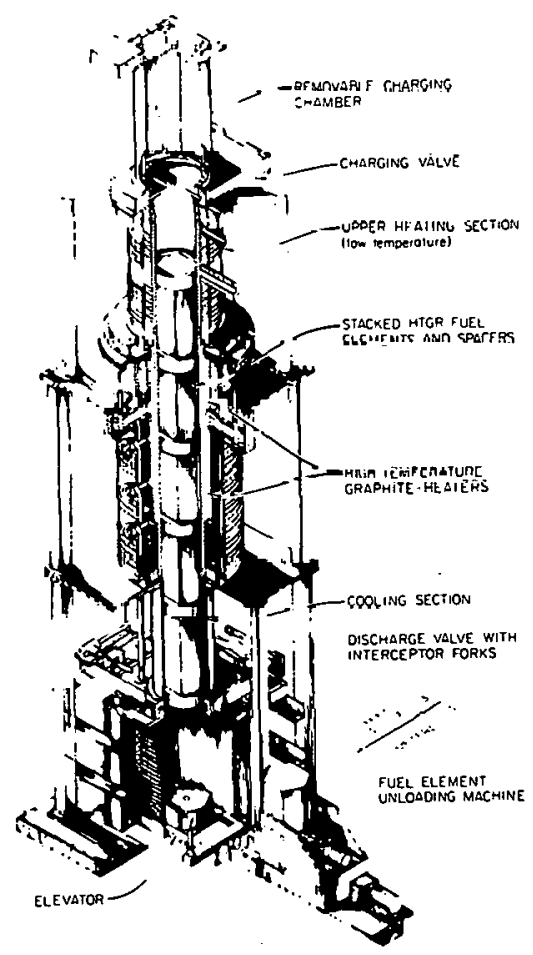

Fig. 16. Schematic of Engineering-Scale Cure-in-Place Furnace. 
is designed as a three-module, vertically stacked unit. Fuel elements are loaded at the top and are continuously passed down through the furnace. Air locks are provided at each end to protect the furnace inert atmosphere during loading and unloading. The furnace uses metallic resistance heaters in the low-temperature zones and graphite resistance heaters in the high-temperature zones. Design of this furnace is now nearing completion, and fabrication and installation are expected to begin within the next several months.

\section{SAMPLE INSPECTION}

In terms of the impact on the design and operation of a refabrication plant, sample inspection is as important as any one of the major process steps. In the fabrication of nuclear fuel, quality control and assurance inspections are a large cost segment of the total cost of fabrication. Typically in the nuclear industry, 30 to $40 \%$ of the cost of fabrication is directly attributable tu luspection costs.

Sample inspection requirements for the refabrication of HTGR fuel are indicated in Fig. 17. It is anticipated that most of the analysis can be done semiremotely behind shield thicknesses equivalent to 2 to 4 in. (50-100 mm) of lead. Techniques for most of these inspections are available, and the application of any one of these analyses to refabrication does not appear formidable: the major problem lies in the integration of the various analytical units into an efficient inspection line. This integration will rely heavily on the development of efficient sampling and sample transferring techniques. Microspheres are considerably easier than powder to sample and offer the potential of unencapsulated pneumatic transfer. The feasibility of such a process has been demonstrated in the laboratory. Techniques for pneumatic transferring of rabbit-type capsules have also been developed on a laboratory scale.

\section{WASTE AND SCRAP HANDLING}

Waste and scrap handling will have a large impact on the design of a commercial recycle facility, as the space and equipment necessary for these operations will represent a significant fraction of the total requirements for refabrication. The scrap requirements for HTGR refabrication are illustrated in Table 1 . For every kilogram of uranium leaving the plant in a fuel element, $0.43 \mathrm{~kg} U$ must be processed as scrap. These rejection rates are based on conservative engineering estimates and, hopefully, rates will be somewhat less in actual operations.

The waste and scrap system, which is unique to HTGR refabrication, is shown in Fig. 18. Other systems - such as liquid waste treatment, nonburnable contaminated waste treatment, and off-gas cleanup - are common to reprocessing development. In the "perc" recovery system, it is anticipated that the perchloroethylene that is used in treating offgas from the carbonization, coating, and cure-in-place furnaces will be recovered by distillation and that the still bottoms will be incinerated. 


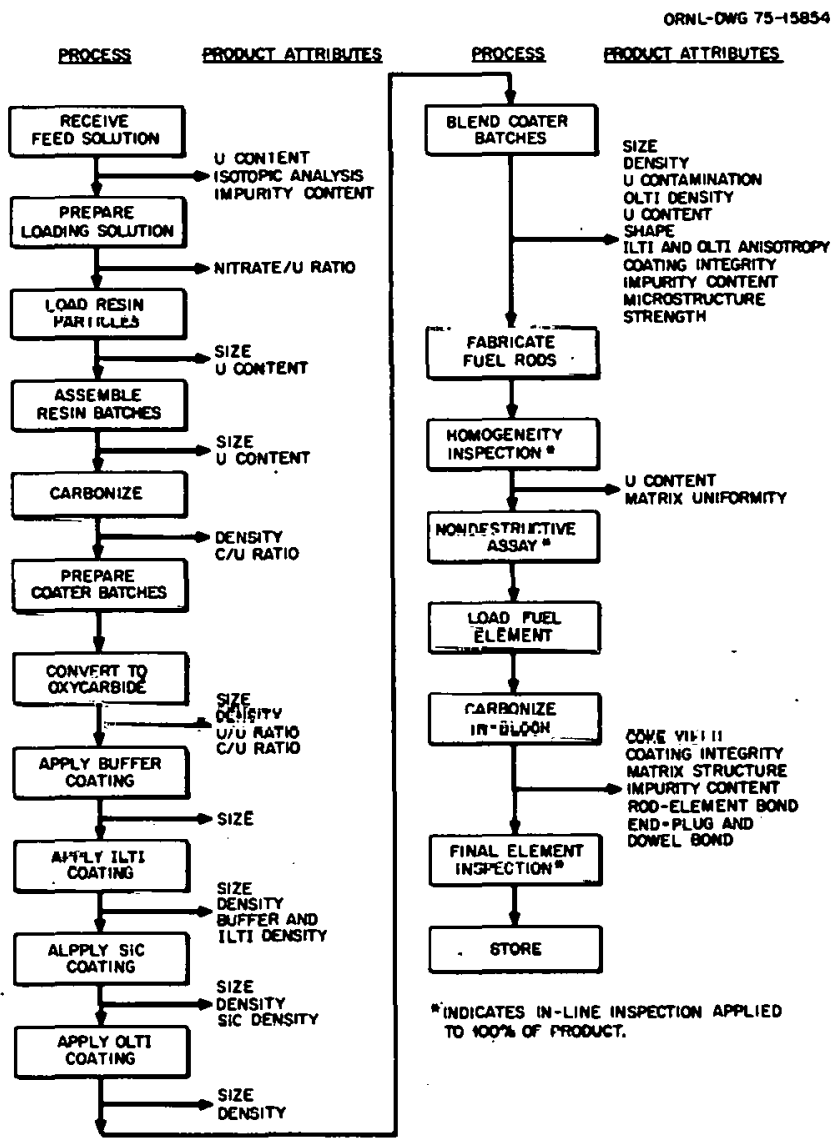

Fig. 17. Processing Operations and Quality Control Requirement for Eabrication of Recycle HTGR Fuel.

Table 1. Estimate of the HTGR Refabrication Process and Scrap Requirements

\begin{tabular}{lcc}
\hline \multicolumn{1}{c}{ Process Step } & $\begin{array}{c}\text { Rejected } \\
\text { per Step } \\
(\%)\end{array}$ & $\begin{array}{c}\text { Units Required per } \\
\text { Unit of Product }\end{array}$ \\
\hline Kernel Preparation & 7.0 & 1.43 \\
Kernel Carbonization & 6.0 & 1.3 \\
Kernel Conversion and Coating & 17.4 & 1.2 \\
Fuel Rod Fabrication & 2.0 & 1.03 \\
Fuel Element Assembly & 1.0 & 1.01 \\
Fuel Element Storage & 0 & 1.0 \\
\hline
\end{tabular}




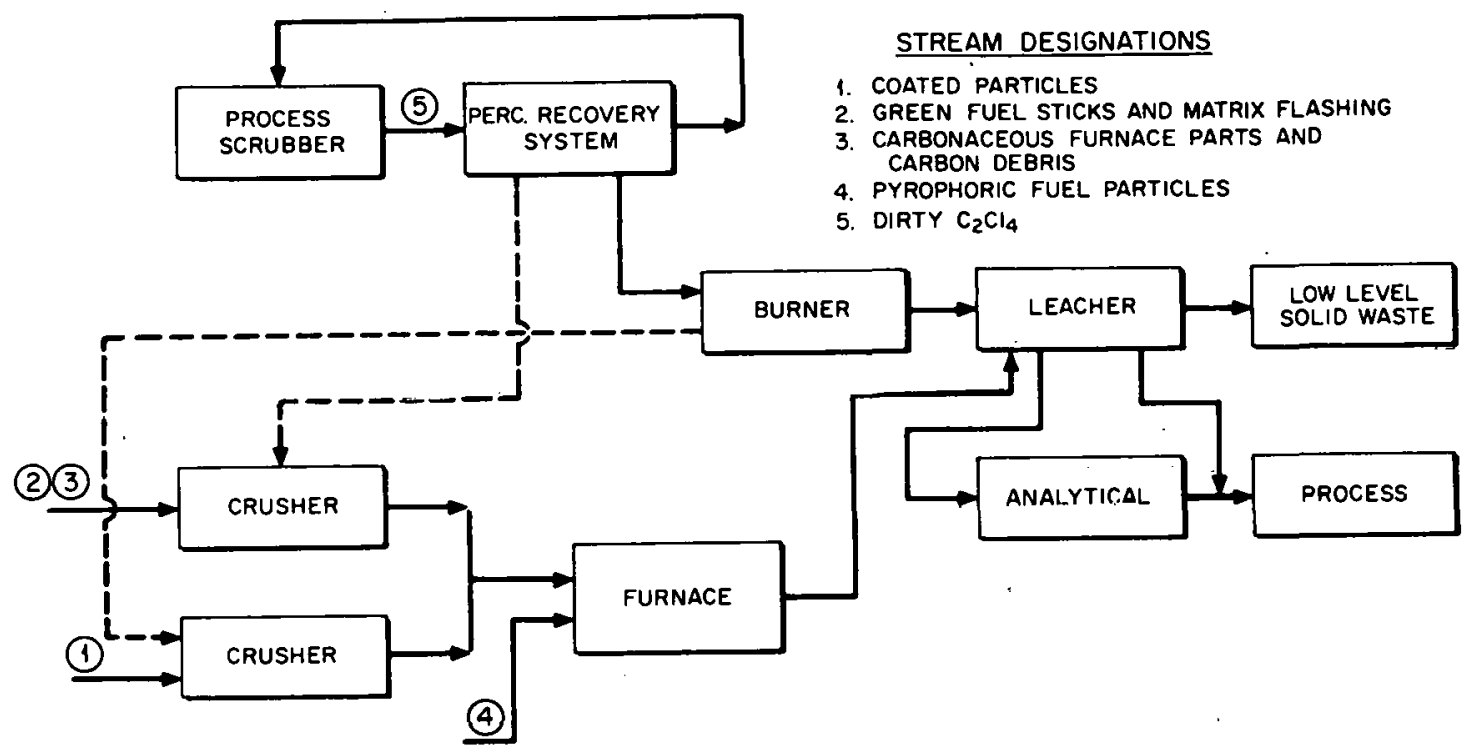

Fig. 18. Schematic Flowsheet of Scrap and Waste Systems Unique to HTGR Refabrication.

For scrap recovery, it is planned that reject fissile material will be crushed, burned, leached with $\mathrm{HNO}_{3}$, and returned to the reprocessing facility as uranyl nitrate solution. Development work in waste and scrap handling is currently in the cold laboratory phase.

\section{PROCESS INTEGRATION AND CONTROL}

The HTGR refabrication process is primarily composed of a series of relatively complex mechanical manufacturing operations. Experience with these types of operations in a completely remotely operated and maintaincd facility is very limfted and on a commercial scale is nonexistent. Without a doubt, the level of automation of a refabrication plant will equal or exceed that of the most modern automatic production lines. In addition, the material accountability and the quality assurance requirements greatly exceed those of most production operations. To meet these requirements, it is envisloned that computer-based instrumentation will be used throughout the plant. The individual process steps will be decoupled by the addition of appropriate surge capacities between them. To preserve the gains in process decoupling, each process system will be supported by a dedicated unit coutroller.

The integration of all the systems into an operating production line is one of the most crucial issues facing the successful operation of an HTGR refabrication plant, and the success will rely heavily on the implementation of the instrumentation and data handling. 


\section{SUMMARY AND CONCLUSIONS}

The feasibility of essentially all processes for remote refabrication of HTGR fuel has been proven by cold and hot laboratory development. The principal exception is in the area of waste and scrap handling; however, laboratory work in these areas is now showing good progress. In terms of equipment development, cold ellyineering equipment has been designed for essentially all major equipment items, and most of this equipment is either in the fabrication or testing phase. Major engineering-scale equipment items currently being tested include ful1scale resin loading and carbonization equipment, and a 5-in.-diam (0.13-m) coater. F'lans for hor englueiting testing of the refabrication processes are now being formulated. Design of the equipment for cold prototype testing is just beginning.

Remote fabrication on a commercial scale will réquire lil all pliases of design, construction, and operation exactness far greater than has been required in any previous high-volume manufacluting operation for reactor fuel. This exactness will require a significant development program to iron out the many details that will spell the difference between success and failure of such an operation. We have come a long way in development of refabrication processes and equipment, but much work still remains - not so much in terms of process feasibility and major equipment configuration, but in terms of details necessary to assure reliability.

\section{ACKNOWLEDGMENTS}

The information described in this report represents the work of many people over a number of years. The lead devclopment engineers of the refabrication development task of the Thorium Ut1l1zation Program at ORNL are responsible for the development of the processes and equipment described in this report. Currently they are R. A. Bradley, P. A. Haas, W. J. Lackey, D. R. Johnson, W. H. Pechin, W. R. Hame1, J. D. Jenkins, and A. R. Ulsen. Leaders of the Enginecring design of the equipment described were J. W. Hill, L. E. Lav1C, M. K. Tyestan, W. G. Cobb, J. W. Snyter, and R. M. DeLozier. The leader for Chemical Technology support was K. J. Notz and for Analȳticàl Chewlsliy support, D. A. Costanzo. We would also like to express our appreciation to the many engineers and technicians who have worked so dillgently on the Thorium Utilization Program at URNL over the last ten to twelve years. 


\section{REFERENCES}

1. Hill, J. W., et al., "Refabrication Pilot Plant (Subtask 220)," Thorium Utilization Progrom Progress Report Jan. 1, 1974-June 30, 1975, Oak Ridge National Laboratory report, ORNL-5128, pp. 225-276.

2. General Atomic Company, Conceptual Design Summary and Design Qualifications for HTGR Target Recycle Plant, GA-A-13365 (to be published).

3. Stewart, H. B., P. R. Kasten, R. C. Dahlberg, A. L. Lotts, L. J. Colby, and G. L. Ritter, "Utilization of Thorium Cycle in the HTGR," pp. 433-47 in Peaceful Uses of Atomic Energy, Proc. 4th Intern. Conf. Geneva (Sept. 6-16, 1971), Vol. 4, United Nations, New York, and International Atomic Energy Agency, Vienna (1972).

4. Till, J. E., "A Comparison of the Potential Radiological Impact of Recycle ${ }^{23}{ }^{3}$ U HTGR Fuel and LMFBR Plutonium Fuel Released to the. Environment," Oak Rldge Nàtiona $\perp$ Laboratory, ORNL/TM-.4768 (January 1975).

5. Arnoid, E. D., "Radiation Hazards of Recycled $233^{3}$-Thorium Fuels," p. 254 in Froceedirys of the Ihorium Fuel Cycle Symposium, Gatlinburg, Tennessee, December 5-7, 1962, USAEC Report TID-7650, Book 1.

6. Turner, R. F., W. V. Goeddel, and E. O. Winkler, "HTGR Fuel Design," pp. 31-48 in Symposium on Sol-Gel Processes and Reactor Fuel Cycle, Gatlinburg, Tennessee, May 4-7, 1970, CONF-700502.

7. Huddle, R.A.U., J.F.G. Conde, and M.S.T. Price, "The Manufacture of the First Charge of Fuel and Fuel Elements for the Dragon Reactor," Paper presented at Seventh Conference on Carbon, Cleveland, Ohio, June 21-25, 1965; Dragon Project report 356.

8. Hackstein, K. G., "Experiments with the Production of AVR-Fuel Elements," pp. 610-18 in Proocedings of Gus-Cooled Reactor Information Meeting at the Oak Ridge National Laboratory, Apriz 27-30, 19\%0, oak Ridge, Tennessee, CONF-700401.

9. Colby, L. J., Jr., Nucl. News 19(1), 68 (January 1976).

10. Symposium on Sol-Gel Processes and Reactor Fuel Cyrle, Gatlinburg, Terriessee, May 4=7, 1870, CONF-700502. 


\section{THIS PAGE \\ WAS INTENTIONALLY \\ LEFT BLANK}


ORNL/TM-5334

UC-77 (Gas-Cooled

Reactor Technology)

\section{INTERNAL DISTRIBUTION}

1-2. Central Research Library

3. Document Reference Library

4-13. Laboratory Records Department

14. Laboratory Records, ORNL RC

15. ORNL Patent Office

16. P. Angelini

17. R. J. Beaver

18. R. A. Bradley

19. A. L. Boch

20. A. J. Caputo

21. J. A. Carpenter, Jr.

22. J. H. Coobs

23. W. H. Couk

24. D. A. Costanzo

25. F. L. Culler

26. J. E. Cunningham

27. F. C. Davis

28. R. G. Donnelly

29. W. P. Eatherly

30. D. E. Ferguson

31. T. G. Godfrey, Jr.

32. P. A. Haas

33. W. R. Hamel

34. R. L. Hamner

35. F. E. Harrington

36. C. C. Haws

37-39. M. R. Hill

40. R. M. Hill

41. F. J. Homan

42. J, D. Jenk.ins

43. D. R. Johnson

44. M. S. Judd

45. M. J. Kania
46-47. P. R. Kasten

48. R. K. Kibbe

49. R. W Knoll

50. W. J. Lackey

51. E. L. Long, Jr.

52-56. A. L. Lotts

57. J. E. Mack

58. A. P. Malinauskas

59. S. R. McNeany

60. K. J. Notz

61. A. R. Olsen

62. W. H. Pechin

63. S. Peterson

64. H. Postma

65. D. P. Reid

66. J. E. Rushton

67. C. D. Scott

68-77. J. D. Sease

78. J. H. Shaffer

79. J. W. Snider

80. D. P. Stinton

81. R. R. Suchomel

82. D. B. Trauger

83. J. E. Van Cleve

84. T. N. Washburn

85. G. W. Weber

86. J. R. Weir, Jr .

87. R. G. Wymer

88. P. M. Brister (ronsultant)

89. John Moteff (consultant)

90. Hayne Palmour III (consultant)

91. J. W. Prados (consultant)

92. N. E. Promisel (consultant)

93. D. F. Stein (consultant) 
EXTERNAL DISTRIBUTION

94-95. ERDA DIVISION OF NUCLEAR FUEL CYCLE AND PRODUCTION, Washington, DC 20545

Director

96-97. ERDA DIVISION OF REACTOR DEVELOPMENT AND DEMONSTRATION, Washington, DC 20545

Director

98-99. ERDA OAK RIDGE OPERATIONS OFFICE, P.O. Box E, Oak Ridge, TN 37830

Director, Reactor Division

Research and Technical Support Division

100-266. ERDA TECHNICAL INFORMATION CENTER, Offtce of Information Services, P. ח. Bnx 62, Oak Ridge, TN 37830

For distribution as shown in TID-4500 Distribution Category, UC-77 (Gas-Cooled Reactor Technology)

267-304. ERDA Exchange Agreements with Germany and Dragon Project 